\title{
Research on the Impact of Financing Liquidity on Risk-taking of Commercial Banks
}

\author{
Yumeng $\mathrm{Bu}^{1, \mathrm{a}}$ \\ ${ }^{1}$ Tianjin University of Finance and Economics, China
}

\begin{abstract}
Insufficient liquidity and maturity mismatches lead to bank risks and financial crises. After Basel III included the net stable funding ratio into regulatory indicators, the relationship between the liquidity indicators represented by the net stable capital ratio and the bank's risk exposure triggered discussions among domestic and foreign scholars. This paper uses the data of China's commercial banks, mainly discussing the mutual influence of internal financing liquidity and external financing liquidity on the risk exposure of banks, and then putting forward some suggestions on how to reduce bank risks through financing liquidity.
\end{abstract}

\section{Introduction}

In 2008, the global financial crisis led to the bankruptcy of many large capital-rich banks in the world, which was attributed to poor liquidity management. When liquidity was excessive, banks were more inclined to hold more risky assets with poor liquidity. Banks have serious maturity mismatches. When liquidity is tight, the liquidity of high-risk assets becomes poor, and there are problems with bank financing channels. When existing liquid assets cannot meet the liquidity needs of banks, a run-off may occur, which may trigger Bank crisis, even lead to bankruptcy. Therefore, liquidity plays an important role in bank risk. Liquidity includes market liquidity and financing liquidity. Market liquidity refers to the difficulty of asset holders in selling assets. Financing liquidity refers to the difficulty of obtaining funds from the market by fund demanders. In December 2012, the Basel Bank Regulatory Commission (BCBS) officially promulgated the Basel III: International Framework for Liquidity Risk Measurement, Standards and Monitoring, which proposed two standards for liquidity risk regulation: liquidity funding coverage ratio (LCR) and net stable funding ratio (NSFR)[1]. NSFR takes the bank's financing liquidity and asset liquidity into account, and aims to promote banks to fund their activities with a more stable source of funds to reduce the maturity of maturity between assets and liabilities.

Although the improvement of financing liquidity can improve bank liquidity, the bank's risk-taking behavior is also stimulated. And when bank risk-taking behavior dominates, the increase in bank risk exposure offsets the benefits of improved liquidity, leading to an increase in bank risk levels. The question explored in this paper is how financing liquidity affects the risk exposure of commercial banks.

\section{Financing liquidity}

The amount of financing and the cost of financing which are two aspects of financing liquidity have different effects on bank risk. From the perspective of financing quantity, the effect of financing liquidity on bank risk is similar to that of market liquidity, and the better the financing liquidity is, the more the financing quantity is, which will encourage banks to hold more risky assets and increase their risks. From the point of view of financing cost, financing liquidity is different from market liquidity. The better the financing liquidity is, the lower the financing cost is, which reduces the incentive for banks to hold risky assets and improves the risk situation of banks.

\subsection{External financing liquidity indicators}

For external financing liquidity, since China mainly focuses on indirect financing, existing literatures generally use pledge repurchase rate, inter-bank offered rate[2] or the spread between inter-bank offered rate and OIS as agency variables of external financing liquidity. Since OIS is not used in China, the proportion of funds raised by Chinese commercial banks using pledge repurchase is far higher than that obtained by using inter-bank borrowing. Therefore, this paper takes the inter-bank mortgage repurchase rate as an indicator to measure the external financing liquidity of commercial Banks. Figure 3 shows the seven-day pledge repurchase rate between China's commercial Banks from 2009 to 2018. 


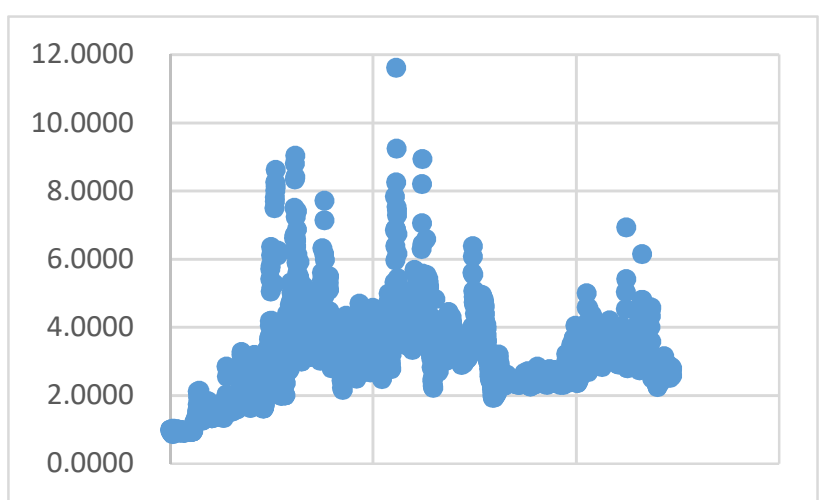

Figure 1. Seven-day pledge repurchase rate between China's commercial banks.

During the period of systemic risk and liquidity crisis, it is difficult for commercial banks to raise funds through inter-bank lending market. When the bank's pledge repurchase rate rises, banks have to pay more to get the money, resulting in higher financing cost and reduced financing liquidity of the bank. Although pledged repurchase financing alleviates liquidity crisis of financial institutions, it increases risk contagion among financial institutions and discount sales in financial markets, thus increasing systemic risk. Therefore, commercial banks should avoid inter-bank lending and pledge repurchase financing in times of liquidity crisis.

The most direct policy solution is to inject liquidity into the banking system or standing lending facility, so as to reduce the liquidity tension in the banking sector and at the same time help reduce systemic risks in the banking sector.

\subsection{Internal financing liquidity indicators}

In the existing literature, scholars take the gap between over-liquidity liabilities and liquidity assets, liquidity coverage ratio, core financing rate, net stable capital rate and other indicators as internal liquidity indicators to measure the relationship between over-liquidity liabilities and risk taking. The most important problem for China's commercial bank is the term mismatch. NSFR which takes the bank's financing liquidity and asset liquidity into account comprehensively, aims at promoting the bank to provide funds for its activities from a more stable capital source, so as to reduce the maturity mismatch between assets and liabilities. NSFR has been gradually included into the liquidity supervision system in China[1], so the internal liquidity index in this paper is calculated by NSFR. According to the Basel III and predecessors' studying results to measure of China's commercial Banks NSFR, net stable funding ratio of large bank and small bank in China is shown in figure 2, from 2008 to 2016.

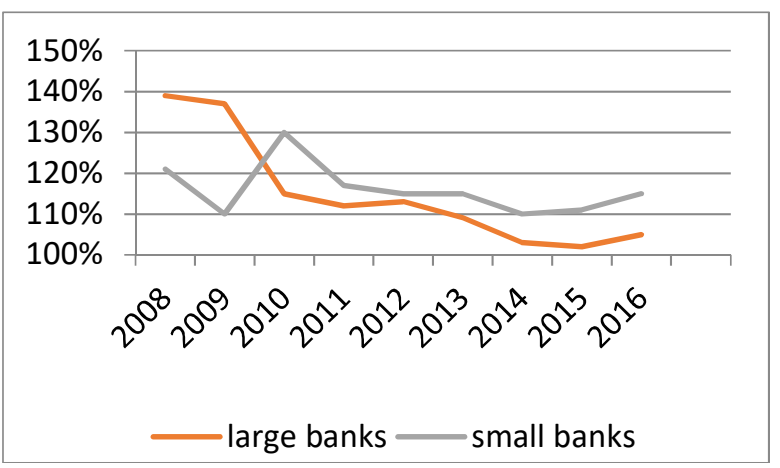

Figure 2. NSFR of large bank and small bank in China.

It can be seen that the proportion of net stable funding of China's commercial Banks meets the requirements of supervision, and the value is greater than 1 . However, within the sample interval, it tends to decline as a whole, indicating that NSFR measures that the financing liquidity of Banks decreases and the risk of Banks increases. Improving net stable funding ratio is to adjust the term structure of assets and liabilities. For China's Commercial Banks, the specific methods include reducing inter-bank borrowing and short-term wholesale financing, expanding long-term wholesale financing over one year, improving the quality and level of non-interest business, expanding the breadth and depth of intermediate business and so on.

\section{A measure of risk-taking}

Most of the existing literatures measure the risk- taking of banks by the ratio of risk-weighted assets to total assets, the ratio of loan loss reserve to total assets, the ratio of non-performing loans, the probability of expected default, $\mathrm{Z}$-score and so on. Z-score is mainly used to measure the risk of bankruptcy. However, China's commercial banks are generally guaranteed by the government credit, basically will not face bankruptcy risk. While perfecting regulation policy in China, but there is a big commercial bank non-performing loans operation data compliance, regulatory risk, so the current domestic and foreign scholars on the Chinese banking industry's actual real level still have doubts, banks non-performing loan ratio is much higher than actual disclosure level, commercial banks are suspected of cover up bad loans. In this paper, the non-performing loan ratio and the risk-weighted asset ratio are used to represent the risk-bearing of commercial banks. Figure 3 shows the relationship between the liquidity ratio of commercial banks and the non-performing loan ratio from 2010 to 2017.

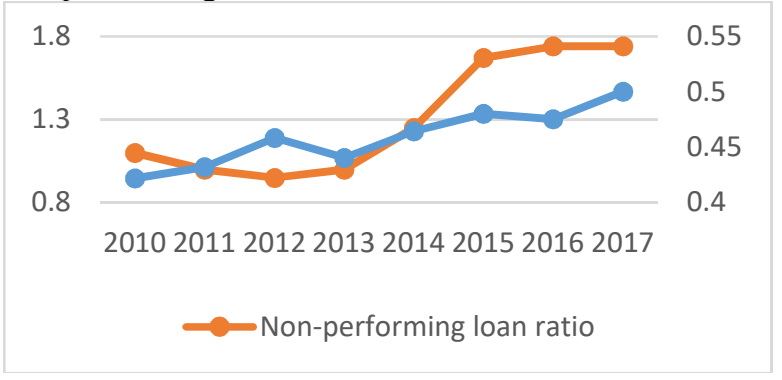

Figure 3. Non-performing loan ratio and liquidity ratio. 
It can be seen that both the liquidity ratio and the non-performing loan ratio as a whole have shown an upward trend in recent years, although liquidity has increased. However, the risk assumption of commercial banks is also expanding, which requires measures to increase liquidity and reduce bank risk.

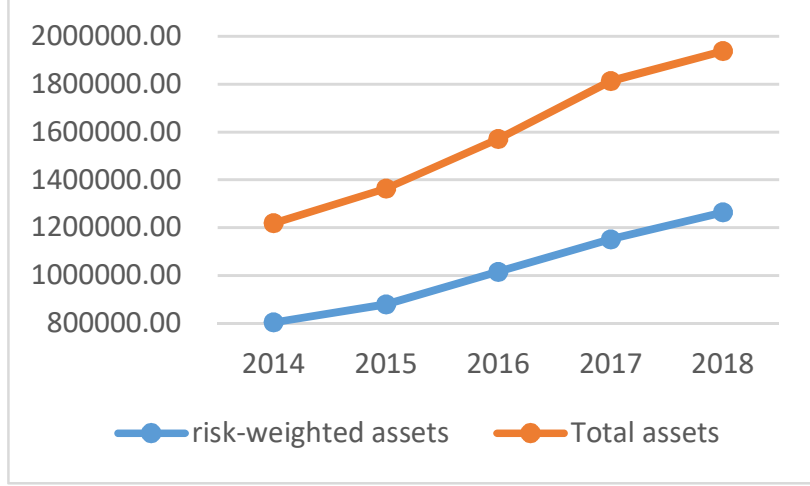

Figure 4. Risk-weighted assets and total assets of China's commercial banks.

Figure 4 shows the number of risk-weighted assets and total assets of China's commercial banks during the period 2014-2018. It can be seen that the number of risk-weighted assets and total assets is rising, but the increase in risk-weighted assets is smaller than the increase in total assets. From the angle of risk-weighted assets, the risk-taking of China's commercial banks tends to decrease.

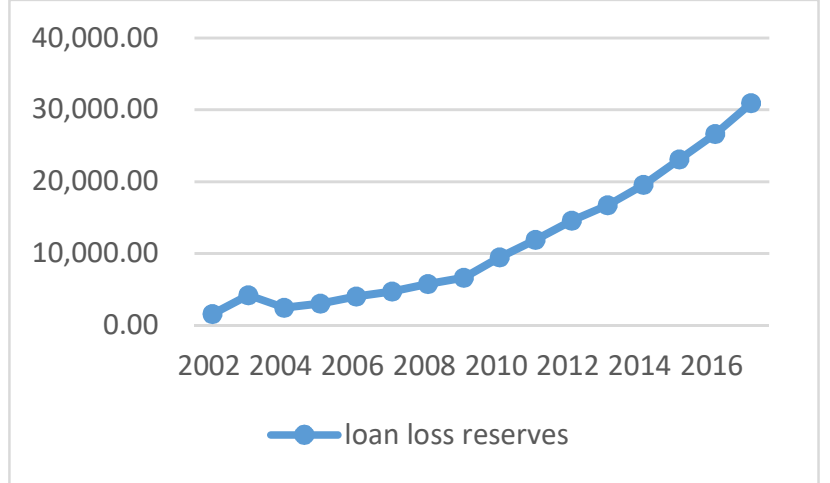

Figure 5. Loan loss reserves of China's commercial banks.

Figure 5 shows the amount of loan loss reserves of Chinese commercial banks. Increasing loan loss reserve ratio can reduce bank losses, reduce the uncertainty risks faced by banks and adjust the risk-taking effect of banks. The bank's loan loss reserve plays an important role in reducing the bank's risk taking and improving its ability to resist risks. Besides strengthening the bank's capital supervision and liquidity supervision, the bank's loan loss reserve plays an important role. It is possible to bring the situation of bank loan loss reserve into the scope of supervision, improve the system of corresponding loan loss provisions, determine the minimum loan loss reserve ratio, the provision of time such as rules of loan loss provisions.

Two aspects of financing liquidity financing quantity and financing cost have different effects on bank risks. From the perspective of financing quantity, financing liquidity has a similar effect on bank risks as market liquidity. The better the financing liquidity is, the more financing quantity increases, which stimulates Banks to hold more risky assets and improves bank risks. From the perspective of financing cost, financing liquidity is different from market liquidity. The better the financing liquidity is, the lower the financing cost, which reduces the incentive for Banks to hold risky assets and improves the risk situation of Banks.

\section{Conclusion}

The increase of internal financing liquidity and external liquidity of commercial banks can significantly reduce the default risk of commercial banks.

First of all, controlling the financing liquidity of commercial banks is still the key to control default risk in China. Secondly, internal and external financing liquidity has different effects on default risk. After the increase of internal financing liquidity, the commercial bank default risk will only respond after one period on average. In contrast, if external financing liquidity rises, commercial banks will respond to default risks in the same period. Therefore, the default risk of commercial banks has a faster response to its external financing liquidity. Central Bank and Banking regulators are important participants in the inter-bank market. In the event of a liquidity crisis, they can take advantage of this feature and quickly inject liquidity into the inter-bank market by participating in reverse repurchase and inter-bank lending markets. This can effectively and timely control the outbreak and spread of the default risk of commercial banks, and ensure the stability of the banking system. In the long run, the default risk of commercial banks is more affected by the liquidity of banks' internal financing.

\section{Suggestions to reduce bank risk-taking}

The government needs to take steps to reduce bank risk.

First of all, improve China's liquidity supervision system, enrich the connotation of indicators, strengthen liquidity supervision, broaden the financing channels of banks, under the trend of the continuous development of financial markets in China. It is more necessary to restrict the risk-taking behavior of banks through strict supervision of net stable funding ratio, to match the development of financial markets with the supervision of bank risks, and to promote banks to operate prudently.

Secondly, since there are significant differences in the policy environment, development background and financing ability of different types of commercial banks in China, different supervision measures should be taken for different types of banks.

Finally, strengthening the information disclosure work of commercial banks and disclosing the data of various financing liquidity indicators as soon as possible will help to make up for the gap of regulatory information, improve the transparency of supervision, and help scholars to study deeply. It is helpful to test the effect of supervision more accurately and put forward feasible suggestions. 


\section{References}

1. Minghui Li. Basel III net stable funding ratio of commercial banks, the influence of the evidence from China's banking sector. J. International financial research, 347(3):51 62(2016).
2. Wagner $\mathrm{W}$. The liquidity of bank assets and banking stability. J. Journal of Banking \& Finance, 31(1): 121 139(2007).

3. Wei X, Gong Y, Wu H M. The impacts of NetStable Funding Ratio requirement on banks' choices of debt maturity. J. Journal of Banking \& Finance, 82: 229 243(2017). 